\title{
Characteristics of Gintonin-Mediated Membrane Depolarization of Pacemaker Activity in Cultured Interstitial Cells of Cajal
}

Byung Joo Kim ${ }^{a}$ Joo Hyun Nam b,c Kyun Ha Kim ${ }^{d}$ Myungsoo Joo ${ }^{d}$ Tal Soo Hae Kwon Yeon Weon ${ }^{f}$ Seok Choig Jae Yeoul Jun ${ }^{g}$ Eun Jung Park ${ }^{\text {h }}$ Jinhong Wie ${ }^{\text {h }}$ Insuk So ${ }^{h}$ Seung-Yeol Nahi

aDivision of Longevity and Biofunctional Medicine, Pusan National University School of Korean Medicine, Yangsan, bDepartment of Physiology, Dongguk University College of Medicine, Kyungju, 'Channelopathy Research Center (CRC), Dongguk University College of Medicine, Goyang, dDivision of Applied Medicine, Pusan National University School of Korean Medicine, Yangsan, eDepartment of Biomedical Science, Daegu University, Gyeongsan, ${ }^{\mathrm{f} C a t h o l i c ~ U n i v e r s i t y ~ o f ~ D a e g u ~ C o l l e g e ~ o f ~ P h a r m a c y, ~}$ Gyeongsan, 9Department of Physiology, Chosun University College of Medicine, Gwangju, hDepartment of Physiology, Seoul National University College of Medicine, Seoul, 'Department of Physiology, Konkuk University College of Veterinary Medicine and Veterinary Science Research Institute, and Bio/Molecular Informatics Center, Seoul, Republic of Korea.

\section{Key Words}

Interstitial Cells of Cajal • Ginseng gintonin • Gastrointestinal tract • ANO1

\begin{abstract}
Background/Aims: Ginseng regulates gastrointestinal (GI) motor activity but the underlying components and molecular mechanisms are unknown. We investigated the effect of gintonin, a novel ginseng-derived G protein-coupled lysophosphatidic acid (LPA) receptor ligand, on the pacemaker activity of the interstitial cells of Cajal (ICC) in murine small intestine and GI motility. Materials and Methods: Enzymatic digestion was used to dissociate ICC from mouse small intestines. The whole-cell patch-clamp configuration was used to record pacemaker potentials and currents from cultured ICC in the absence or presence of gintonin. In vivo effects of gintonin on gastrointestinal (GI) motility were investigated by measuring the intestinal transit rate (ITR) of Evans blue in normal and streptozotocin (STZ)-induced diabetic mice. Results: We investigated the effects of gintonin on pacemaker potentials and currents in cultured ICC from mouse small intestine. Gintonin caused membrane depolarization in current clamp mode but this action was blocked by Ki16425, an LPA1/3 receptor antagonist,
\end{abstract}

B. J. Kim and J. H. Nam contributed equally to this work and should be considered joint first authors.

Seung-Yeol Nah

and Byung Joo Kim
Department of Physiology, Konkuk University College of Veterinary Medicine and Veterinary Science Research Institute, and Bio/Molecular Informatics Center, Seoul 143701, (Republic of Korea) and Division of Longevity and Biofunctional Medicine, Pusan National University School of Korean Medicine, Yangsan 626-870, (Republic of Korea)

E-Mail synah@konkuk.ac.kr and E-Mail vision@pusan.ac.kr 
and by the addition of GDP $\beta$, a GTP-binding protein inhibitor, into the ICC. To study the gintonin signaling pathway, we examined the effects of U-73122, an active PLC inhibitor, and chelerythrine and calphostin, which inhibit PKC. All inhibitors blocked gintonin actions on pacemaker potentials, but not completely. Gintonin-mediated depolarization was lower in $\mathrm{Ca}^{2+}$-free than in $\mathrm{Ca}^{2+}$-containing external solutions and was blocked by thapsigargin. We found that, in ICC, gintonin also activated $\mathrm{Ca}^{2+}$-activated $\mathrm{Cl}^{-}$channels (TMEM16A, ANO1), but not TRPM7 channels. In vivo, gintonin $(10-100 \mathrm{mg} / \mathrm{kg}, p .0$.$) not only significantly increased$ the ITR in normal mice but also ameliorated STZ-induced diabetic GI motility retardation in a dose-dependent manner. Conclusions: Gintonin-mediated membrane depolarization of pacemaker activity and ANO1 activation are coupled to the stimulation of GI contractility through LPA1/3 receptor signaling pathways in cultured murine ICC. Gintonin might be a ingredient responsible for ginseng-mediated GI tract modulations, and could be a novel candidate for development as a prokinetic agent that may prevent or alleviate GI motility dysfunctions in human patients.

Copyright (C) 2014 S. Karger AG, Basel

\section{Introduction}

Ginseng, the root of Panax ginseng C.A. MEYER, is a popular herbal medicine that is consumed as a functional health food throughout the world. From ancient times, ginseng has been believed to have various beneficial effects on the cardiovascular system, central and peripheral nervous systems, and the immune system [1-4]. Furthermore, recent studies showed that ginseng increased mouse ileal movement [5], accelerated the relaxation of gastric circular muscle, and stimulated longitudinal muscle contraction in the distal colon of the guinea pig [6]. In the rabbit GI tract, ginseng was found to have stimulatory effects on intestinal motility [7]. In addition, Daikenchuto (DKT), which contains ginseng as a main ingredient, is used to regulate intestinal motility $[8,9]$. However, the active components and underlying molecular mechanisms for the GI motility effects of ginseng are not fully understood.

Interstitial cells of Cajal (ICC) are the pacemaker cells of the GI system and have multifunctional roles. Absence or reduced numbers of ICC causes abnormally slow electrical waves and reduces smooth muscle cell contractility and intestinal transit [1012]. In addition, the loss of ICC is implicated in several motility disorders, which suggests that ICC play an important role in the regulation of GI motility [13]. In addition, evidence indicates that endogenous agents, such as, neurotransmitters, hormones, and paracrine substances, modulate GI tract motility by influencing ICC [14]. It has been shown that the pacemaker activities of ICC in the murine small intestine are mainly due to periodic activations of nonselective cation channels (NSCCs) $[15,16]$ or $\mathrm{Cl}^{-}$channels [17-22]. Kim et al. [16] suggested that transient receptor potential melastatin (TRPM) 7 is required for ICC pacemaker activity in the murine small intestine, and a $\mathrm{Ca}^{2+}$-activated $\mathrm{Cl}^{-}$channel (CaCC) is involved in slow wave generation in ICC. This channel is the transmembrane protein $16 \mathrm{~A}$ (Tmem16A) [18]. Tmem16A encodes the anoctamin 1 (AN01) channel, which is expressed in human embryonic kidney (HEK)-293 cells [18, 23-26]. Additionally, other research groups have suggested that inwardly rectifying $\mathrm{Cl}^{-}$channels [19], volume-activated chloride channels [20], a high-conductance chloride channel (which was renamed to the maxi-channel) [21, 22], ether-a-go-go-related gene (ERG) potassium channels [27], nonselective cation channels [28] and voltage dependent $\mathrm{Ca}^{2+}$ channels [29] play prominent roles in determining pacemaker activity in the gut. However, the role of Tmem16A in pacemaker activity in ICC was identified in TMEM16A knockout mice [30], and many papers have suggested that Tmem16A participates in pacemaker activity [25, 26, 30]. Additionally, Shahi et al. [31] showed that ANO1 mRNA was expressed in cultured ICC. Accordingly, it has been proposed that TRPM7 and ANO1 may be important targets for the pharmacological treatment of GI motility disorders. 
Recently, we isolated a novel ligand, gintonin, of the ginseng-derived G protein-coupled lysophosphatidic acid (LPA) receptor [32,33] and demonstrated that gintonin effectively activates LPA receptors in cells expressing LPA receptors endogenously or heterologously [32]. Furthermore, the activation of LPA receptors by gintonin was found to affect cell survival, proliferation, migration, and morphological changes in neuronal and non-neuronal

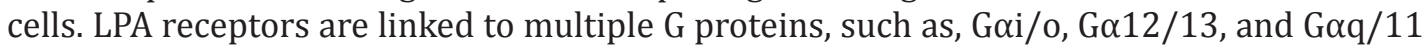
[32], and LPA receptor activation by gintonin is linked to diverse downstream events, which include the stimulation of phospholipase C (PLC), mitogen-activated protein kinases, and phosphoinositide 4-kinase (PI4-kinase) [32]. In addition, gintonin has been reported to regulate various ion channels, such as $\mathrm{Ca}^{2+}$-activated $\mathrm{K}^{+}\left(\mathrm{BK}_{\mathrm{Ca}}\right)$ and voltage-gated $\mathrm{K}^{+}$channels through LPA receptors [34, 35].

LPA receptors are also expressed in GI systems [36, 37], but relatively little is known about the effects of LPA on the pacemaker activity of ICC in the GI tract and GI motility-related ion channel activity. In the present study, we investigated the effects of gintonin, as a ginsengderived LPA receptor ligand, on the pacemaker potentials of cultured ICC, and characterized gintonin-mediated signaling pathways. Also, we investigated the effects of gintonin on GI motor functions in normal and diabetic conditions by measuring the intestinal transit rate (ITR) of Evans blue in mice. We found that gintonin induces membrane depolarization of pacemaker activity via LPA receptors, induces ANO1 channel activation, and increases GI motility. We further discuss the possible application of gintonin for development as a prokinetic agent that might be used to treat disease-related GI motility dysfunctions in humans.

\section{Materials and Methods}

\section{Preparation of cells and cell cultures}

Animal care and experiments were conducted in accordance with the principles issued by the ethics committee of Pusan National University (Republic of Korea). Balb/c mice were used throughout the study. Small intestines (from $1 \mathrm{~cm}$ below the pyloric ring to the cecum) were removed and opened along the mesenteric border. Luminal contents were removed using Krebs-Ringer bicarbonate solution, and the tissues obtained were pinned to the base of Sylgard dishes. The mucosa was removed by sharp dissection, and small tissue strips of intestine muscle (consisting of both circular and longitudinal muscles) were equilibrated for $30 \mathrm{~min}$ in $\mathrm{Ca}^{2+}$-free Hank's solution (containing (in mM); KCl 5.36, $\mathrm{NaCl} 125$, $\mathrm{NaOH} \mathrm{0.34,}$ $\mathrm{Na}_{2} \mathrm{HCO}_{3} 0.44$, glucose 10, sucrose 2.9 and HEPES 11; pH 7.4). Cells were then dispersed in an enzyme solution containing collagenase (Worthington Biochemical, Lakewood, NJ, U.S.A., $1.3 \mathrm{mg} \mathrm{ml}^{-1}$ ), bovine serum albumin (BSA, Sigma-Aldrich, St Louis, MO, U.S.A., $2 \mathrm{mg} \mathrm{ml}^{-1}$ ), trypsin inhibitor (Sigma-Aldrich, $2 \mathrm{mg} \mathrm{ml}^{-1}$ ), and ATP $\left(0.27 \mathrm{mg} \mathrm{ml}^{-1}\right)$, and plated onto sterile glass coverslips coated with murine collagen $\left(2.5 \mu \mathrm{g} \mathrm{ml}^{-1}\right.$; Falcon/BD, Franklin Lakes, NJ, U.S.A.) in a $35 \mathrm{~mm}$ culture dish. Cells were then cultured at $37^{\circ} \mathrm{C}$ in a $95 \% \mathrm{O}_{2}$ $5 \% \mathrm{CO}_{2}$ incubator in smooth muscle growth medium (SMGM; Clonetics, San Diego, CA, U.S.A.) supplemented with $2 \%$ antibiotics/antimycotics (Gibco, Grand Island, NY, U.S.A.) and murine stem cell factor (SCF; 5 $\mathrm{ng} \mathrm{ml}^{-1}$; Sigma-Aldrich). All experiments on ICC clusters were performed on $24 \mathrm{hrs}$ and single ICC were performed on cells cultured within $12 \mathrm{hrs}$. ICC were identified immunologically using an anti-c-kit antibody (phycoerythrin (PE)-conjugated rat anti-mouse c-kit monoclonal antibody; eBioscience, San Diego, CA) at a dilution of 1:50 for 20 min (Fig. 1).

\section{Patch-clamp experiments}

The physiological salt solution used to bathe cultured ICC clusters ( $\mathrm{Na}^{+}$-Tyrode) contained (in mM): $\mathrm{KCl} 5$, NaCl 135, $\mathrm{CaCl}_{2} 2$, glucose $10, \mathrm{MgCl}_{2} 1.2$, and HEPES 10 (adjusted to $\mathrm{pH} 7.4$ with $\mathrm{NaOH}$ ). The pipette solution used to examine pacemaker activity contained (in $\mathrm{mM}$ ): $\mathrm{KCl} 140, \mathrm{MgCl}_{2} 5, \mathrm{~K}_{2} \mathrm{ATP}$ 2.7, NaGTP 0.1, creatine phosphate disodium 2.5, HEPES 5, and EGTA 0.1 (adjusted to pH 7.2 with $\mathrm{KOH}$ ). To record the TRPM7 like currents, the single cells were bathed in a solution containing (in mM): $\mathrm{KCl} 2.8, \mathrm{NaCl} 145, \mathrm{CaCl}_{2}$ 2, glucose $10, \mathrm{MgCl}_{2} 1.2$, and HEPES 10, adjusted to $\mathrm{pH} 7.4$ with $\mathrm{NaOH}$. The pipette solution contained (in $\mathrm{mM}$ ): Cs-glutamate 145, $\mathrm{NaCl}$ 8, 1,2-bis(o-aminophenoxy)ethane- $\mathrm{N}, \mathrm{N}, \mathrm{N}^{\prime}, \mathrm{N}^{\prime}$-tetraacetic acid (BAPTA) 10, 
Kim et al.: Effects of Gintonin on ICC

and HEPES-CsOH 10, adjusted to $\mathrm{pH} 7.2$ with $\mathrm{CsOH}$. To record the $\mathrm{Ca}^{2+}$ activated $\mathrm{Cl}^{-}$(ANO1/TMEM16A) currents, the single cells were bathed in a solution containing (in mM): NMDG-Cl 150, HEPES 10, glucose 10, $\mathrm{CaCl}_{2} 1$, and $\mathrm{MgCl}_{2} 1$ (adjusted to $\mathrm{pH}$ 7.4), and the pipette solution contained NMDG-Cl 150, HEPES 10, MgATP 3, and EGTA 0.1 (adjusted to pH 7.2). Patch-clamp techniques were conducted in the whole-cell configuration to record membrane currents (voltage clamp) and potentials (current clamp) from cultured ICC using Axopatch I-D and Axopatch 200B amplifiers (Axon Instruments, Foster, CA). Command pulses were applied using an IBM-compatible personal computer and pClamp software (version 6.1 and version 10.0; Axon Instruments). Data were filtered at $5 \mathrm{kHz}$ and displayed on an oscilloscope, a computer monitor, and/or a pen recorder (Gould 2200; Gould, Valley View, OH, USA). The results were analyzed using pClamp and Origin software (version 6.0, Microcal, USA). All experiments were performed at $30-33^{\circ} \mathrm{C}$.

\section{Immunohistochemistry}

Cultured ICC within $12 \mathrm{hrsfrom}$ the small intestines of Balb/C mice were used for immunohistochemistry. Cultured ICC were fixed in cold acetone $\left(4^{\circ} \mathrm{C}\right)$ for $5 \mathrm{~min}$, washed in phosphate-buffered saline (PBS; 0.01 $\mathrm{M}, \mathrm{pH}$ 7.4), and immersed in $0.3 \%$ Triton X-100 in PBS. After blocking with $1 \%$ BSA in $0.01 \mathrm{M}$ PBS for 1 hour at room temperature, cells were incubated with a rat monoclonal antibody raised against c-Kit (Ack2; eBioscience) at $0.5 \mu \mathrm{g} / \mathrm{ml}$ or with a rabbit polyclonal antibody against ANO1 in PBS for 24 hours $\left(4^{\circ} \mathrm{C}\right)$. After rinsing in $\mathrm{PBS}$ at $4^{\circ} \mathrm{C}$, cells were labeled with fluorescein isothiocyanate (FITC)-coupled donkey anti-rabbit IgG secondary antibody (1:100; Jackson Immunoresearch Laboratories, Bar Harbor, MN, U.S.A.) or Texas red-conjugated donkey anti-rat IgG (1:100, Jackson Immunoresearch Laboratories) for 1 hour at room temperature. For double immunostaining, specimens were incubated with a mixture of antibodies raised against ANO1, and antibody raised against c-kit for $24 \mathrm{~h}$ at $4^{\circ} \mathrm{C}$. After thorough washing with PBS, the mixture of labeled secondary antibodies was incubated for 1 hour at room temperature. Cells were examined under an FV 300 laser scanning confocal microscope (Olympus, Tokyo) at an excitation wavelength appropriate for FITC (495 nm) or Texas red (590 nm). Final images were constructed using Flow-View software (Olympus).

\section{Measurement of the ITR of Evans blue}

The effect of each test drug on intestinal propulsion was assessed by measuring the intestinal transit of an Evans blue solution ( $5 \%, w / v$, in DW). At 30 min after the intragastric (i.g.) administration of gintonin in normal or mice, the Evans blue solution was administered i.g. to the mice through an orogastric tube at a volume of $0.1 \mathrm{ml} /$ body. In the streptozotocin (STZ)-induced diabetic mice, the Evans blue solution was administered i.g. in the same manner. The animals were then sacrificed $30 \mathrm{~min}$ after the administration of the Evans blue solution, and the intestinal transit of the Evans blue during the 30 min period was determined by measuring the distance that the Evans blue migrated in the intestine from the pylorus to the most distal point of the intestine. Intestinal transit was expressed as ITR (\%), the percentage of the distance traveled by Evans blue divided by the total length of the small intestine (i.e. from the pylorus to the ileal end). To minimize possible inter-day variations in ITR measurements, the measurement for each model (i.e. normal and STZ-induced diabetic mice) was performed on the same day.

\section{STZ-induced diabetic mouse model}

Male imprinting control region (ICR) mice (at the age of 5 weeks) were used for this study and all experimental protocols were approved by the Animal Care and Use Committee of Pusan National University College of Korean Medicine. The mice were randomly divided into two groups: a control group and a diabetic group. To produce diabetes, food was withheld from mice overnight and STZ (Sigma-Aldrich, St. Louis, MO) solution was then administered intraperitoneally. STZ was prepared fresh in $0.1 \mathrm{~mol} / \mathrm{L}$ ice-cold citrate buffer $(\mathrm{pH}=4.0)$ and used at a dose of $200 \mathrm{mg} / \mathrm{kg}$ body weight. The same volume of $0.1 \mathrm{~mol} / \mathrm{L}$ citrate buffer was administered to control mice intraperitoneally. The animals had free access to food and water and were maintained under standard housing conditions (room temperature $24-27^{\circ} \mathrm{C}$ and humidity 60-65\%) with a $12 \mathrm{~h}$ light and dark cycle. After two months, blood was withdrawn from the tail vein of mice after fasting $8 \mathrm{~h}$ and blood glucose concentration was measured with a one-touch blood glucose monitoring system (Johnson \& Johnson Medical Company). The threshold for diabetes was defined as a blood glucose level above $16 \mathrm{mM}$. 
Fig. 1. Effects of gintonin on pacemaker activity in cultured clusters of murine ICC. (A-C) Pacemaker activities of ICC exposed to gintonin $(0.1 \mathrm{C}$ $=5), 1(n=4), 10 \mu \mathrm{g} /$ $\mathrm{ml}(n=6))$ in currentclamp mode $(\mathrm{I}=0)$. Gintonin produced membrane depolarization in a concentration-dependent manner and decreased pacemaker amplitudes. Responses to gintonin are summarized in (D) and E). Bars represent mean SEs. ${ }^{*} P<0.05$. $* * P<0.01$.

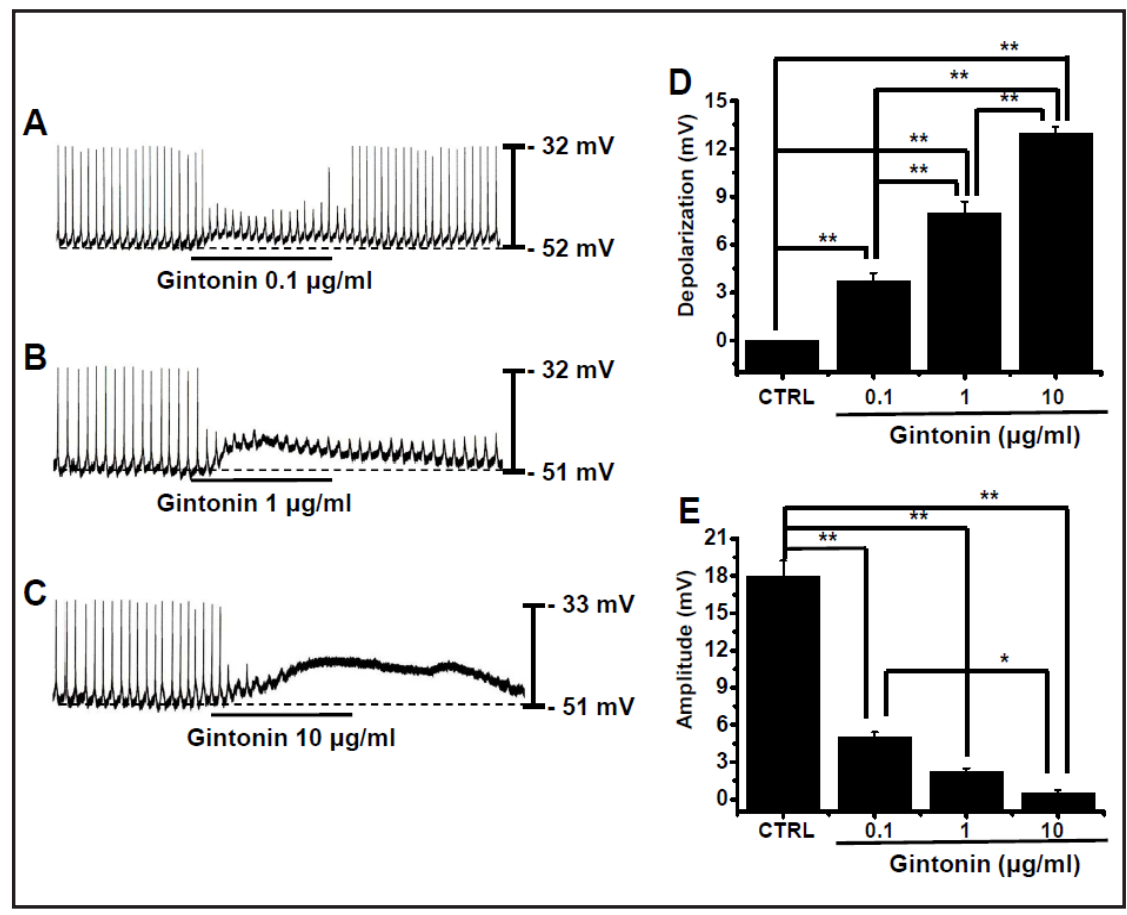

\section{Drugs}

Ki16425 was purchased from Cayman Chemicals (Ann Arbor, MI, USA) and T16Ainh-A01 was purchased from TOCRIS (USA). All other drugs were obtained from Sigma. Stock solutions were prepared and stored, according to the manufacturer's instructions. Chemicals were dissolved in $\mathrm{Na}^{+}$-Tyrode solution to their final concentrations immediately before being used to perfuse cells.

\section{Statistical analysis}

Data are expressed as the means \pm S.E.M.s. Statistical analysis was performed with student's $t$ test or analysis of variance (ANOVA) in GraphPad Prism version 6 followed by Tukey's multiple comparison test, as appropriate. A $P<0.05$ was considered statistically significant. The $n$ values reported in the text refer to the number of cells used in patch-clamp experiments.

\section{Results}

Effects of gintonin on pacemaker activity in cultured ICC clusters

Cultured ICC clusters had a mean resting membrane potential of $-51 \pm 2 \mathrm{mV}$ and produced electrical pacemaker activity at a of frequency $14 \pm 2$ cycles per minute and an amplitude of $18 \pm 3 \mathrm{mV}(\mathrm{n}=45)$ at $30^{\circ} \mathrm{C}$ in current clamp mode. We then examined the effect of gintonin on pacemaker activity.

Gintonin (0.1-10 $\mu \mathrm{g} / \mathrm{ml}$ ) decreased the amplitude and induced the membrane depolarization of pacemaker activity in a concentration-dependent manner (Fig. 1). These results also show that gintonin decreased the amplitude and induced the membrane depolarization of pacemaker activity in a dose-dependent manner.

LPA1/3 receptors were involved in the gintonin-induced depolarization of pacemaker activity

Hwang et al. [32] previously demonstrated that gintonin activates LPA receptors in cells that express LPA receptors either endogenously or heterologously. Therefore, we investigated the relationship between gintonin and LPA receptors.

Initially, we examined the effect of Ki16425 (an LPA 1/3 receptor antagonist [38, 39] on the gintonin-mediated effect on pacemaker activity. In the absence of Ki16425, gintonin 


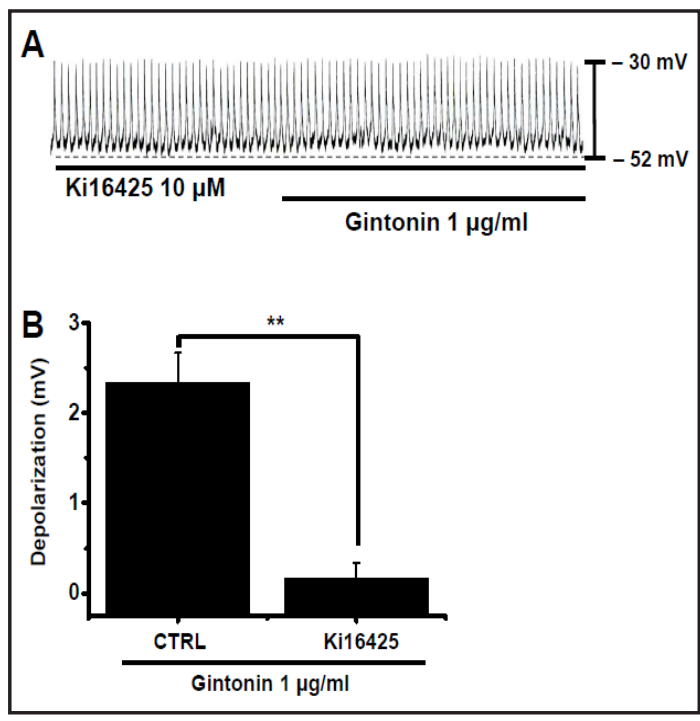

Fig. 2. Effects of an LPA receptor antagonist on pacemaker activity in cultured ICC clusters. (A) Effects of Ki16425 (LPA1/3 receptor antagonist) on gintonin-mediated effects on pacemaker activity. Ki16425 blocked the gintonin-induced depolarization of pacemaker activity. (B) Responses to the LPA antagonist are summarized. Bars represent means \pm SEs. ${ }^{* *} P<0.01$.

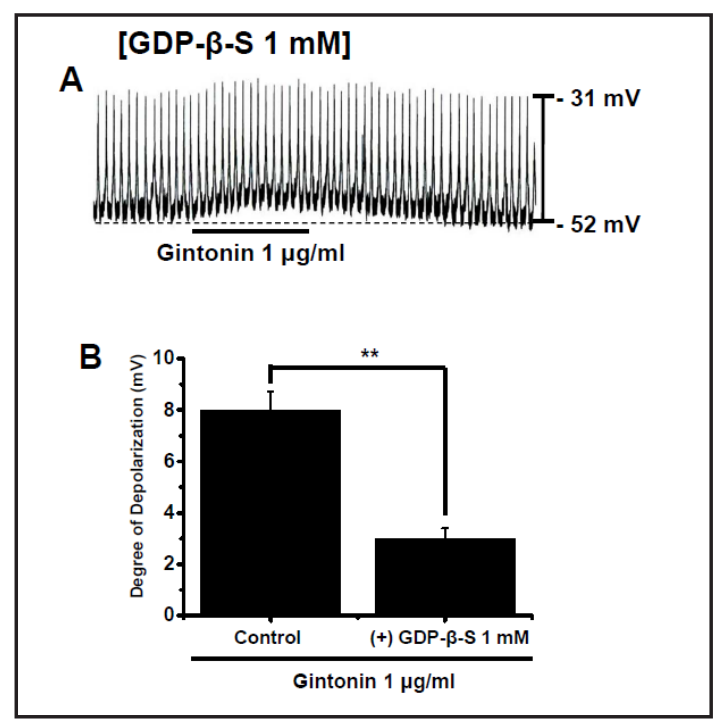

Fig. 3. Effects of GDP $\beta S$ in the pipette on the gintonin-induced depolarization of pacemaker activity in cultured ICC clusters. (A) Pacemaker activities of ICC exposed to gintonin in the presence of GDP $\beta S$ $(1 \mathrm{mM})$ in the pipette solution. Under these conditions, gintonin caused a slight depolarization. (B) Responses to gintonin in the presence of GDP $\beta S$ in the pipette are summarized. Bars represent means \pm SEs. ${ }^{* *} P<0.01$.

induced membrane depolarization of pacemaker activity. However, in the presence of Ki16425, the gintonin effect on pacemaker activity was attenuated (Fig. 2A). The mean depolarization was $0.16 \pm 0.13 \mathrm{mV}$ with Ki16425 (Fig. 2B). These results indicate that gintonin-induced depolarization of pacemaker activity is mediated through the activation of $L P A 1 / 3$ receptors.

\section{Involvement of $G$ proteins on gintonin-induced depolarization of pacemaker activity}

To investigate the signaling mechanisms involved and the roles played by G proteins during the gintonin-induced depolarization of pacemaker activity, we applied GDP $\beta S$ (a nonhydrolysable guanosine $5^{\prime}$-diphosphate analogue that permanently inactivates GTP binding proteins $[40,41])$ using patch pipettes.

When GDP $\beta S(1 \mathrm{mM})$ was present in the pipette solution, gintonin-induced depolarizations were lower than under GDP $\beta S$-free conditions $(n=7 ;$ Fig. $3 \mathrm{~A})$. The mean depolarization was $3.2 \pm 0.4 \mathrm{mV}$ in the presence of GDP $\beta$ S (Fig. 3B). These results suggest that gintonin-induced depolarization of pacemaker activity might be associated with $G$ proteins.

\section{Effects of phospholipase $C$ and protein kinase $C$ inhibitors on gintonin-induced} depolarization of pacemaker activity

Because we found that gintonin-induced depolarizations of pacemaker activity were related to GTP-binding proteins, we examined whether ICC pacemaker activity requires PLC activation. Gintonin-induced depolarizations of pacemaker activity were measured in the absence or presence of U-73122 (an active PLC inhibitor) [42]. Gintonin-induced depolarizations of pacemaker activity were completely abolished by U-73122 (5 $\mu \mathrm{M})$, and under these conditions, gintonin-induced depolarizations of pacemaker activity were suppressed (Fig. 4A). In the presence of U-73122, the mean gintonin-induced depolarization of pacemaker activity was $1.4 \pm 0.2 \mathrm{mV}$. Furthermore, the values of gintonin-induced 


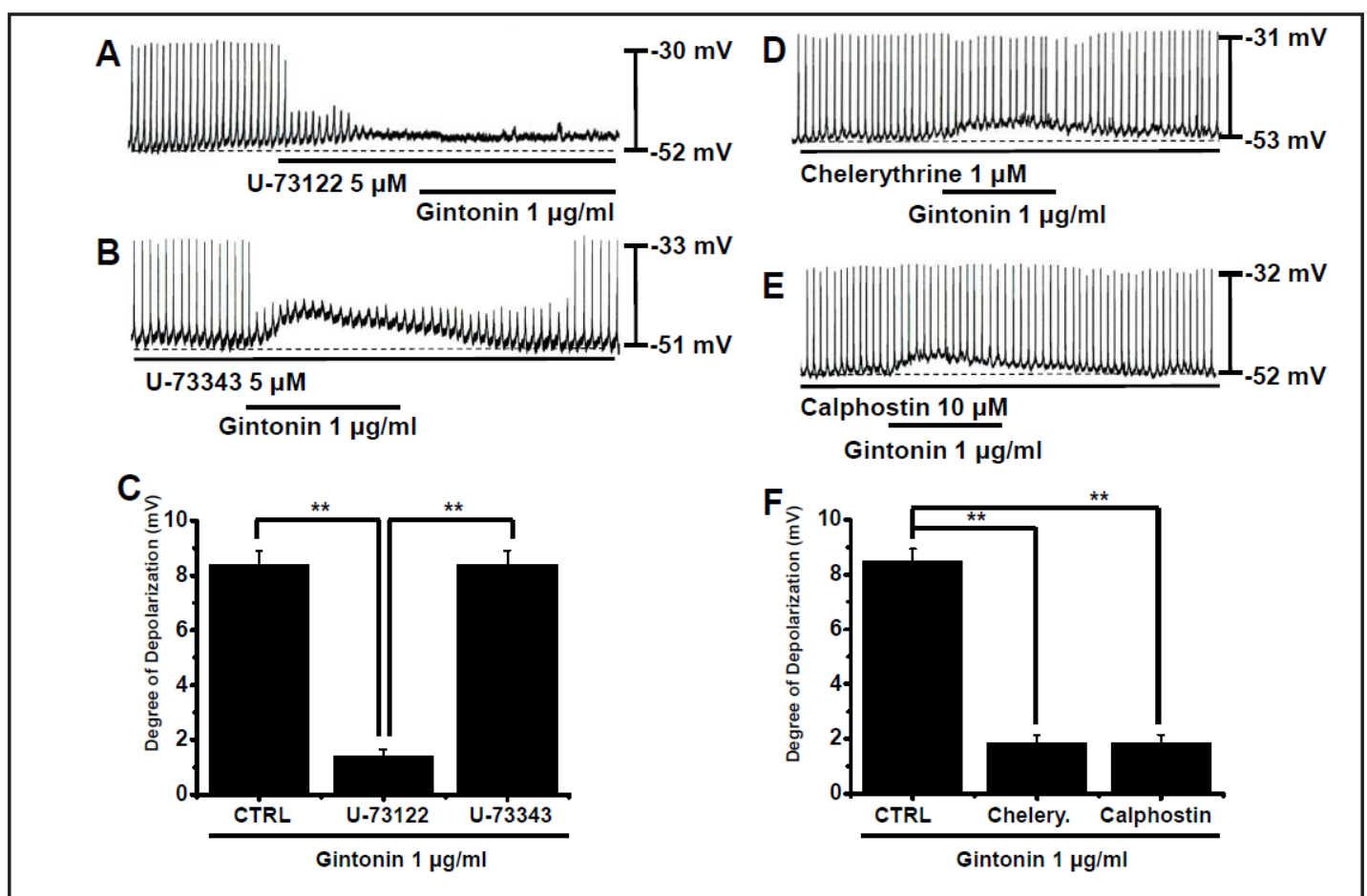

Fig. 4. Effects of U-73122 (a phospholipase C inhibitor) and of chelerythrine or calphostin (protein kinase $\mathrm{C}$ inhibitors) on gintonin-induced depolarization of pacemaker activity in cultured ICC clusters. (A) Pacemaker activities of ICC exposed to gintonin in the presence of U-73122 (5 $\mu \mathrm{M})$. U-73122 blocked the gintonin-induced depolarization of pacemaker activity. (B) Treatment with U-73343 (5 $\mu \mathrm{M}$; an inactive analog of U-73122) had no influence on gintonin-induced depolarizations of pacemaker activity and under these conditions, gintonin-induced depolarizations of pacemaker activity were not suppressed by U-73343. (C) Responses to gintonin in the presence of U-73122 or U-73343 are summarized. (D) Pacemaker activities of ICC exposed to gintonin in the presence of chelerythrine $(1 \mu \mathrm{M})$ or $(\mathrm{E})$ calphostin $(10 \mu \mathrm{M})$. Chelerythrine or calphostin blocked the gintonin-induced depolarization of pacemaker activity. (F) Responses to gintonin in the presence of chelerythrine or calphostin are summarized. Bars represent means \pm SEs. ${ }^{* *} P<0.01$.

depolarizations of pacemaker activity were significantly lower as compared with those in the absence of U-73122 ( $n=5$; Fig. 4C). Treatment with U-73343 (5 $\mu$ M; an inactive analog of U-73122) had no influence on gintonin-induced depolarizations of pacemaker activity, and under these conditions, gintonin-induced depolarizations of pacemaker activity were not suppressed by U-73343 (Figs. 4B and C).

We also investigated the involvement of PKC in the gintonin-induced depolarizations of pacemaker activity. Chelerythrine and calphostin (PKC inhibitors [43]) were used to investigate whether gintonin-induced depolarizations were mediated by the activation of PKC. Both chelerythrine $(1 \mu \mathrm{M})$ and calphostin $(10 \mu \mathrm{M})$ significantly inhibited gintonininduced depolarizations of pacemaker activity and also blocked the reduction of pacemaker potential amplitude (Figs. 4D and E). In the presence of chelerythrine or calphostin, mean gintonin-induced depolarizations of pacemaker activity were $1.8 \pm 0.4 \mathrm{mV}$ for chelerythrine and $1.8 \pm 0.3 \mathrm{mV}$ for calphostin $(\mathrm{n}=6$; Fig. $4 \mathrm{~F}$ ). These results suggest that gintonin-induced depolarizations of ICC occur in a PLC- and PKC-dependent manner.

Effects of extracellular $\mathrm{Ca}^{2+}$-free solution and $\mathrm{Ca}^{2+}$-ATPase inhibitor in the endoplasmic reticulum on gintonin-induced depolarization of pacemaker activity

Extracellular $\mathrm{Ca}^{2+}$ influx is essential for the generation of pacemaker activity by ICC and for GI smooth muscle contractions. In addition, the generation of pacemaker activity is also known to be dependent on intracellular $\mathrm{Ca}^{2+}$ oscillations [44]. 


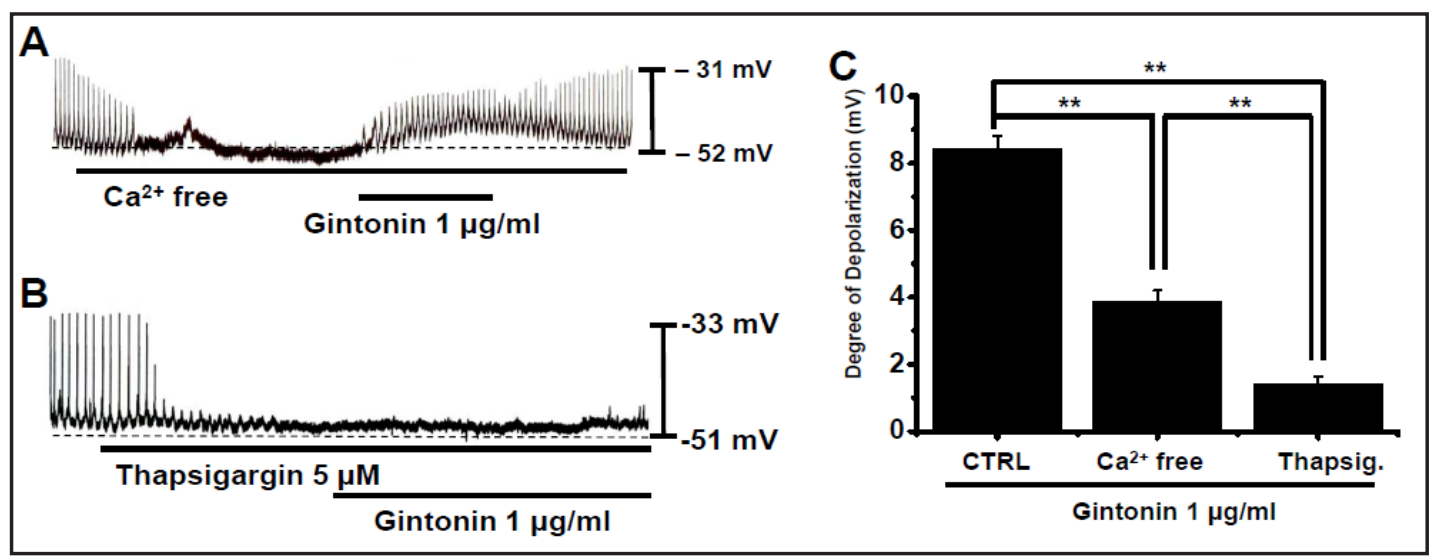

Fig. 5. Effects of an external $\mathrm{Ca}^{2+}$-free solution and of thapsigargin $\left(\mathrm{a} \mathrm{Ca}^{2+}\right.$-ATPase inhibitor in the endoplasmic reticulum) on gintonin-induced depolarization of pacemaker activity in cultured ICC clusters. (A) External $\mathrm{Ca}^{2+}$-free solution abolished the pacemaker activity, but failed to block the gintonin-induced depolarization of pacemaker activity. (B) Thapsigargin ( $5 \mu \mathrm{M})$ abolished pacemaker activity and blocked gintonin-induced depolarization. (C) Responses to gintonin in external $\mathrm{Ca}^{2+}$-free solution and in the presence of thapsigargin are summarized. Bars represent means \pm SEs. ${ }^{* *} P<0.01$.

Fig. 6. Effects of gintonin on TRPM7-like currents in single ICC and the current-voltage $(\mathrm{I}-\mathrm{V})$ relationship using the whole cell patch-clamp technique. (A) Gintonin had no effect on the TRPM7-like currents in single ICC. Slow ramp depolarizations from +100 to $-100 \mathrm{mV}$ were applied from a holding potential of $-60 \mathrm{mV}$ before (1) and during (2) treatment

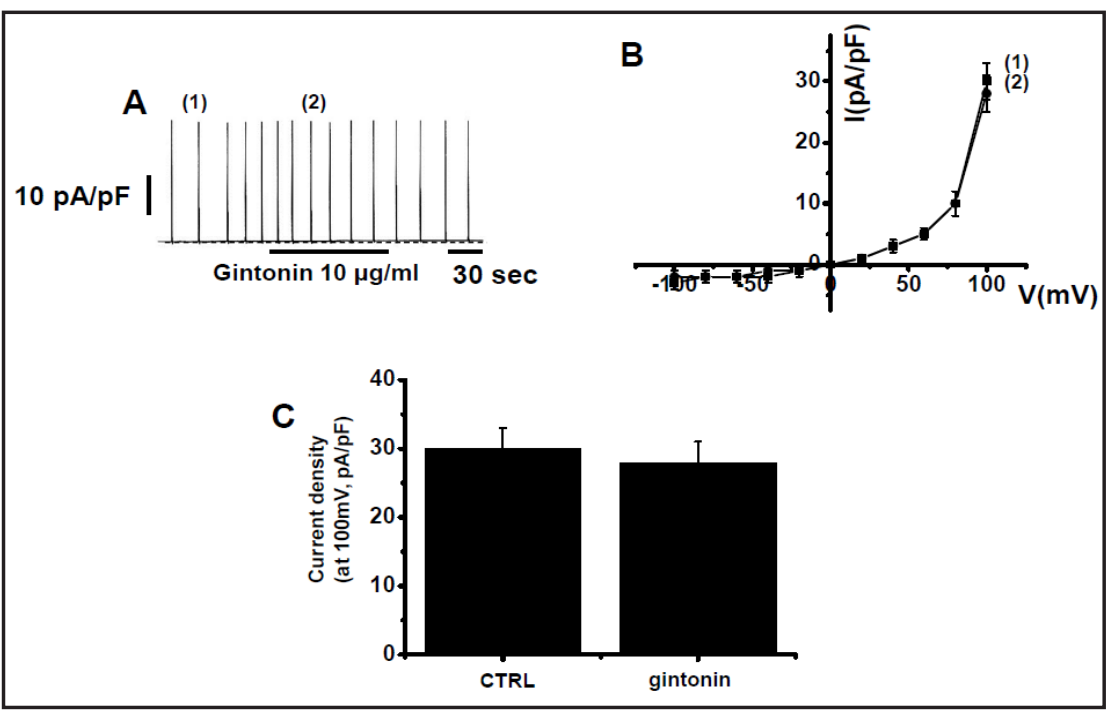
with gintonin. (B) I-V relationships were determined before and during treatment. (C) Responses to gintonin during TRPM7-like currents are summarized. Bars represent means \pm SEs.

To study the roles of extracellular and intracellular $\mathrm{Ca}^{2+}$, the effect of gintonin was investigated under extracellular $\mathrm{Ca}^{2+}$-free conditions and in the presence of thapsigargin (an inhibitor of $\mathrm{Ca}^{2+}$-ATPase) in the endoplasmic reticulum [15, 45]. In the presence of an extracellular $\mathrm{Ca}^{2+}$-free solution, pacemaker activity was greatly attenuated, and gintonininduced depolarizations were lower than in $\mathrm{Ca}^{2+}$-containing solutions $(\mathrm{n}=5$; Fig. $5 \mathrm{~A})$. In addition, in the presence of thapsigargin, pacemaker activity was also completely abolished, and gintonin-induced effects were significantly inhibited $(n=6$; Fig. 5B). The mean depolarization was $3.9 \pm 0.4 \mathrm{mV}$ for external $\mathrm{Ca}^{2+}$-free solutions and $1.4 \pm 0.2 \mathrm{mV}$ with thapsigargin (Fig. 5C). These results show that $\mathrm{Ca}^{2+}$ release from intracellular stores as well as external $\mathrm{Ca}^{2+}$ plays a major role in gintonin-induced depolarization of pacemaker activity.

Gintonin had no effect on TRPM7-like currents

Because the TRPM7 or AN01 channels are involved in pacemaker activity in ICC [1518], we next investigated which ion channel is involved in gintonin action. We applied 
A.

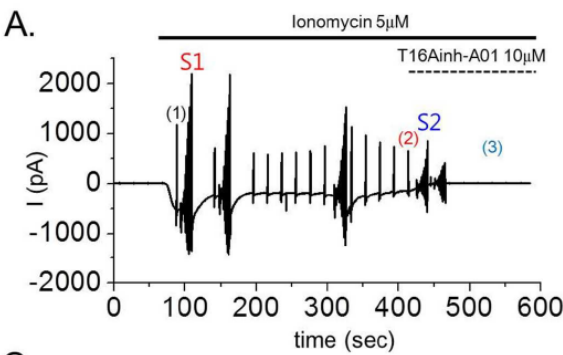

C.

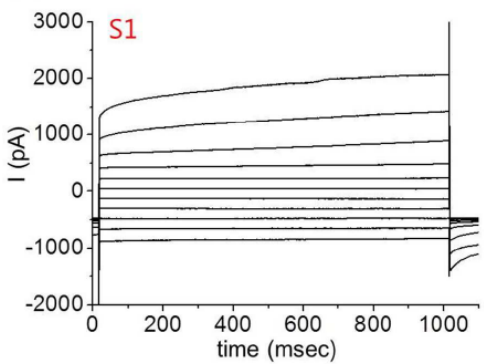

B.

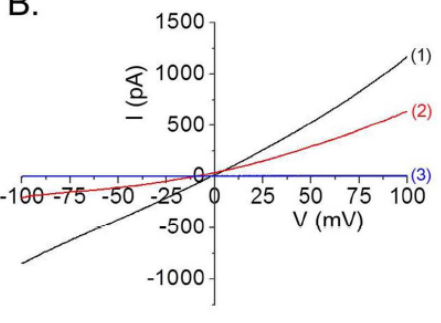

D.

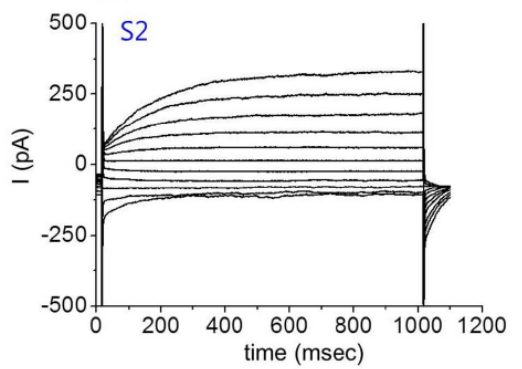

Fig. 7. Ionomycin generates an ANO1-like current in single ICCs. (A) A representative trace of ANO1-like current generation by the application of $5 \mu \mathrm{M}$ ionomycin under a whole-cell patch clamp configuration with symmetrical NMDG-Cl $(150 \mathrm{mM})$ solution (bath and pipette) and $0.2 \mathrm{mM}$ EGTA in the pipette solution. Note the ionomycin induced ANO1-like current was totally inhibited by treatment with a selective ANO1 blocker (T16Ainh-A01, $10 \mu \mathrm{M}$ ). Voltage steps of $1000 \mathrm{~ms}$ duration were given from a holding potential of $-60 \mathrm{mV}$ to voltages between -100 and $+100 \mathrm{mV}$ in $20 \mathrm{mV}$ increments, followed by a step to $-60 \mathrm{mV}$ (S1, S2). (B) I/V curves were obtained by applying a depolarizing ramp pulse from -100 to $100 \mathrm{mV}$ at the initial peak (1) and before (2) and after (3) T16Ainh-A01 application. (C-D) Representative raw current traces obtained from step pulses at the point of S1 and S2 in Fig. 8 (A). All ICC displayed hallmarks of ANO1 currents, including slow time-dependent current activation, and de-activating tail currents upon repolarization by the application of ionomycin.

gintonin on TRPM7-like currents in single ICC and recorded whole cell currents using the patch-clamp technique. To construct current-voltage (I-V) relationships, we applied a ramp pulse from $-100 \mathrm{mV}$ to $+100 \mathrm{mV}$ for $2 \mathrm{~s}$. Perfusing gintonin into the bath solution had no effect on the TRPM7-like currents $(n=6$; Fig. 6). These results suggest that gintonin does not affect TRPM7-like currents in ICC.

\section{Ionomycin generates ANO1-like currents in single ICC}

To investigate whether AN01-like current was existed in ICC, we performed whole cell patch clamp experiments on single ICC. Ionomycin is a calcium ionophore that can increase intracellular calcium concentration by allowing $\mathrm{Ca}^{2+}$ ions from the extracellular bath solution which contains $1 \mathrm{mM} \mathrm{Ca}^{2+}$ to cross cell membranes.

As shown in Fig 7, after confirming no basal $\mathrm{Cl}^{-}$current, the treatment with $5 \mu \mathrm{M}$ ionomycin immediately generated $\mathrm{Cl}^{-}$currents in a whole-cell patch clamp configuration with symmetrical NMDG-Cl (150 mM) solutions (bath and pipette) and $0.2 \mathrm{mM}$ EGTA in pipette solution. At physiologically relevant $\mathrm{Ca}^{2+}$ concentrations $(>1 \mu \mathrm{M}), \mathrm{CaCC}$ display time- and voltage dependent currents. However, as the treatment of ionomycin approaches the intracellular $\mathrm{Ca}^{2+}$ concentration, $\mathrm{CaCC}$ activation becomes saturated and CaCCs lose their time- and voltage-dependence and become almost voltage independent at all membrane potentials (Fig. 7B (1) and 7C).

As shown in Fig 7A (2), CaCCs were inactivated by chronic treatment of ionomycin and the current shows voltage dependent outwardly rectifying characteristics. The I-V relationship is presented at Fig. 7B (2). We also applied voltage step pulses and obtained slow time-dependent current activation, and de-activating tail currents upon repolarization 


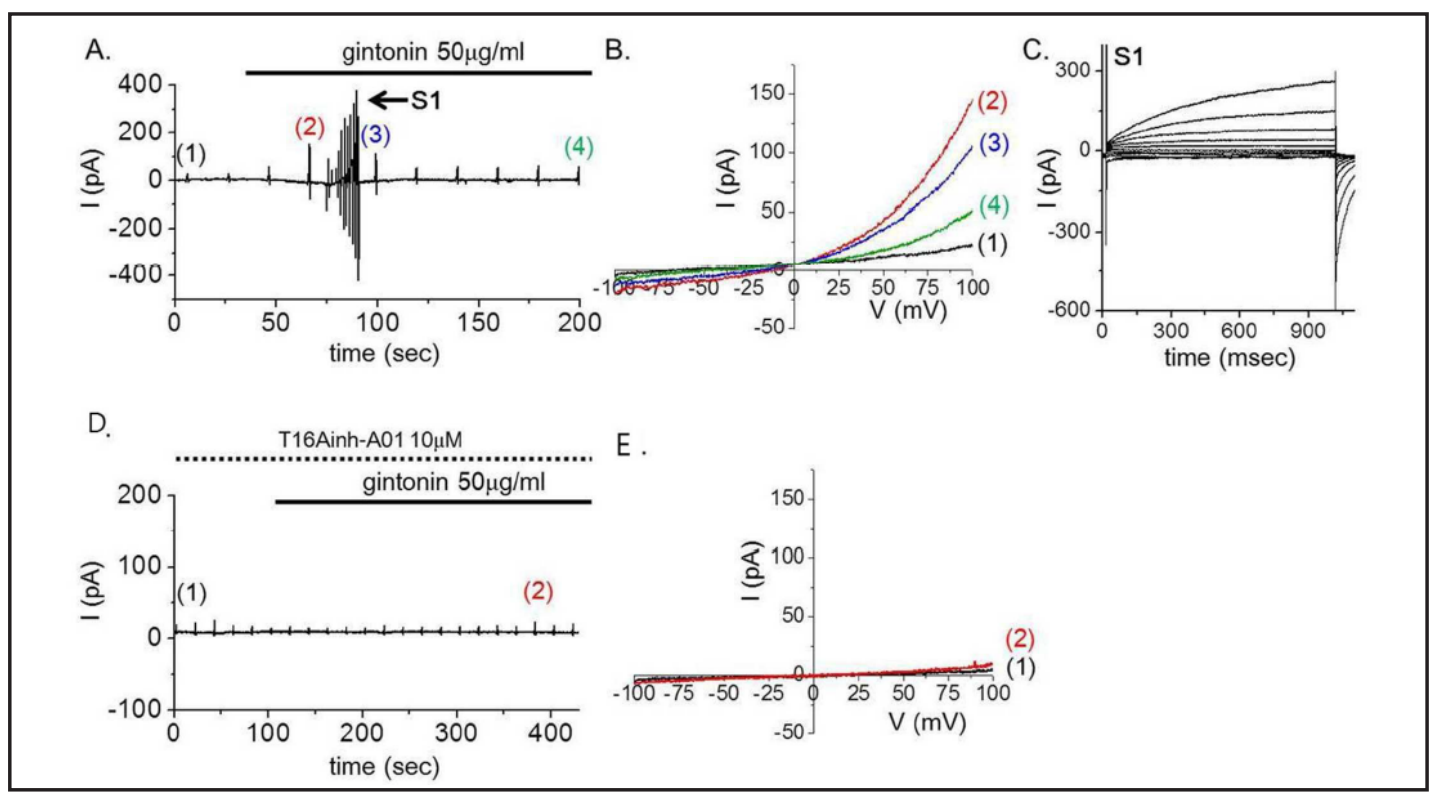

Fig. 8. Gintonin induced ANO1-like $\mathrm{Cl}^{-}$current in single ICC. (A) Typical traces showing ANO1-like $\mathrm{Cl}^{-}$current induced by gintonin $(50 \mu \mathrm{g} / \mathrm{ml})$ in the whole-cell patch clamp configuration with symmetrical NMDG-Cl (150 $\mathrm{mM}$ ) solution (bath and pipette) (A). Whole-cell patch clamp recording was performed by using the same pulse protocol used in the ionomycin experiments (Fig. 1). (B) The I/V curves were obtained in the initial control period (1) and during treatment with gintonin (2-4). (C) The representative time courses of currents by step pulse protocol were obtained at 40 secs after application of gintonin $(50 \mu \mathrm{g} / \mathrm{ml})$. Note the gintonin generated time-dependent strong outward rectifying currents that are the hallmarks of ANO1 currents. (D, E) The pretreatment of T16Ainh-A01 prevents the generation of AN01-like $\mathrm{Cl}^{-}$current induced by gintonin. The original current traces show the blockade of AN01-like $\mathrm{Cl}^{-}$current induced by gintonin. The related I/V relationships were obtained from before (1) and during (2) treatment with gintonin (F).

with the application of ionomycin (Fig 7D). This ANO1-like current was completely abolished by treatment with T16Ainh-A01 which is a selective AN01 blocker (Fig 7A and B (3)).

\section{Gintonin induced ANO1-like Cl current in single ICC}

Next, we assessed whether this ANO1-like current could also be generated by the application of gintonin. As shown in Fig. 8, the application of gintonin $(50 \mu \mathrm{g} / \mathrm{ml})$ (Fig. 8A) immediately activated strong outward rectifying currents that showed slow time-dependent current activation (Fig. 8B), and de-activating tail currents were observed when voltage steps were applied (Fig. 8C). Pre-treatment of single ICC with T16Ainh-A01 blocked the generation of ANO1-like currents by the application of gintonin (Fig. 8D and 8E). These experiments were repeated over 9 trials. In addition, we checked for the presence of ANO1 by immunolabeling in cultured ICC. The co-localization of c-kit (red) and ANO1 (green) in single ICC and ICC clusters produces a yellow color (merge) (Fig. 9). Double labeling of ICC from murine small intestine showed that these proteins were localized in ICC. These results suggest that ANO1 currents are involved in the gintonin-induced effects on ICC.

\section{Effects of gintonin on the ITR in normal and STZ-induced diabetic mice}

The ITRs (\%) of Evans blue over $30 \mathrm{~min}$ in normal and STZ-induced diabetic mice are shown in Fig. 10. The ITR for normal mice with no treatment (control, $n=18$ ) was $63.1 \pm$ $1.8 \%$. However, the ITR values for gintonin administered at 10,50 , and $100 \mathrm{mg} / \mathrm{kg}$ doses were $63.3 \pm 2.1(n=10), 64.2 \pm 1.4(n=12)$, and $67.5 \pm 1.5 \%(n=10)$, respectively $(p<0.05$; Fig. 10A). Therefore, gintonin produced a slight ITR increase. To confirm the effect on GI motility, we tested mice with GI motility dysfunctions including STZ-induced diabetic mice. As expected, a significant retardation in the ITR was observed in STZ-induced diabetic mice 


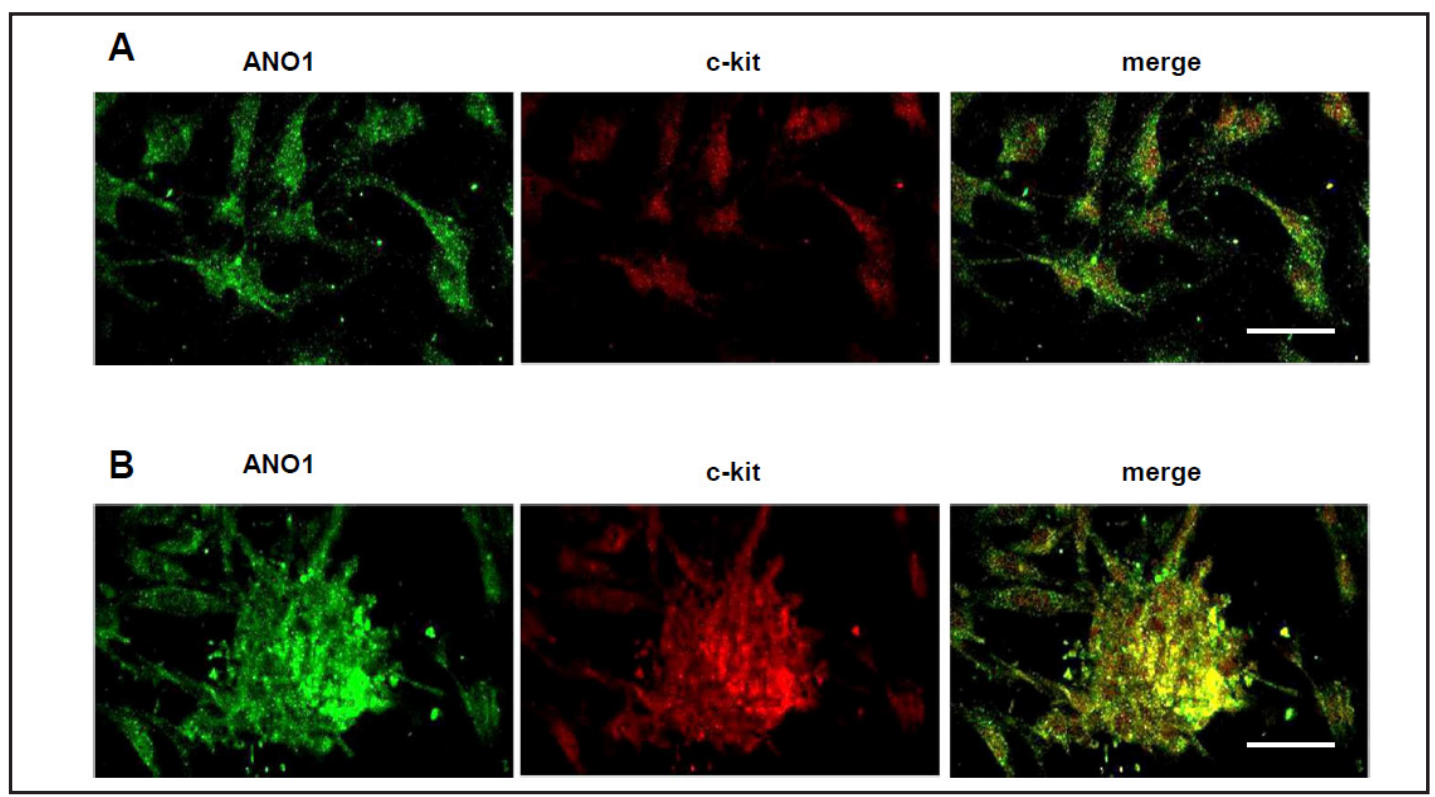

Fig. 9. Expressions of ANO1 proteins in cultured ICC within $12 \mathrm{hrs.} \mathrm{(A)} \mathrm{Double-labeling} \mathrm{of} \mathrm{cultured} \mathrm{single}$ ICC with ANO1 (green) and c-kit (red) antibodies. Cultured ICC showed the co-localization of ANO1 and c-kit immunoreactivities. (B) Double-labeling of cultured ICC cluster with ANO1 (green) and c-kit (red) antibodies. ANO1 and c-kit immunoreactivities were co-localized in cultured ICC cluster. The mixed color yellow indicates the co-localization of ANO1 and c-kit immunoreactivities. Scale bars: $50 \mu \mathrm{m}$.

Fig. 10. Effects of gintonin on ITR in normal and STZ-induced diabetic mice. (A) The ITR (\%) of Evans blue was measured during a $30 \mathrm{~min}$ period following p.o. administration of an Evans blue solution 30 min after pretreatment with gintonin in normal mice. (B) The ITR (\%) of Evans blue was measured during a 30
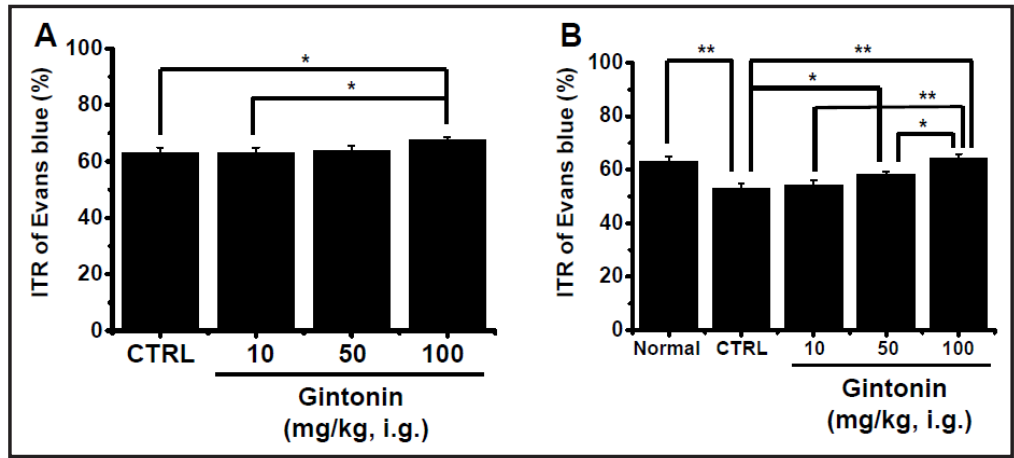

min period following p.o. administration of an Evans blue solution $30 \mathrm{~min}$ after pretreatment with gintonin in STZ-induced diabetic mice. ${ }^{*} p<0.05 .{ }^{* *} P<0.01$.

(53.3 $\pm 1.4 \% ; n=15$, Fig. 10B). However, a significant inhibition of retardation of the ITR was observed for the gintonin $100 \mathrm{mg} / \mathrm{kg}$ dose (p.o. administration) in STZ-induced diabetic mice $(64.6 \pm 1.4 \%(p<0.01) ; n=15$, Fig. 10B). No abnormal clinical signs or changes were observed in STZ-induced diabetic mice for any p.o. doses of gintonin. Gintonin is considered to be safe in mice.

\section{Discussion}

ICC serve as the pacemaker cells of the GI tract by generating spontaneous pacemaker potentials and conducting slow waves into smooth muscle syncytium, because they are electrically coupled to neighboring smooth muscle cells $[10,11,46]$. Smooth muscle cells respond to slow wave depolarization by activating L-type $\mathrm{Ca}^{2+}$ channels [46]. In addition, smooth muscle response is regulated by neural inputs, and both excitatory and inhibitory 
enteric motor neurons are closely associated with ICC [14]. Thus, ICC play an important role in the determination and regulation of GI motility.

In the present study, we found that gintonin inhibited ICC pacemaker activity and depolarized resting membrane potentials via a series of G protein-coupled LPA receptor signaling pathways, including G-protein-PLC-Ca ${ }^{2+}-\mathrm{PKC}$ activation. On the other hand, ICC pacemaker activities are mainly due to periodic activations of non-selective cation channels (NSCCs) [15, 16] or $\mathrm{Cl}^{-}$channels [17-22], and TRPM7 and ANO1 channels are the main candidates for the NSCC and $\mathrm{Cl}^{-}$channels responsible for the pacemaker activity in ICC [18, $25,26,30]$. Therefore, TRPM7 and ANO1 modulators are potential targets for the treatment of GI motility disorders. In this study, gintonin had no effect on TRPM7 channel currents, whereas gintonin activated ANO1 currents, indicating that the ANO1 rather than the TRPM channel is involved in the gintonin-mediated modulation of pacemaker activity in ICC.

LPAs are phospholipid derivatives with a myriad of cellular effects and act as mitogens with hormone and growth factor activities in most cell types and organs [47]. LPAs cause an elevation of the intracellular $\mathrm{Ca}^{2+}$ level and induce cell proliferation, differentiation, morphological changes, migration, and survival through LPA receptor activation [48]. Although the diverse LPA receptor-related cellular functions are linked to activities such as brain development in nervous system, angiogenesis in vascular system, embryo implantation and spermatogenesis in reproductive system, and wound healing, understanding of LPA activity in GI tract is rudimentary. Recent reports have shown that LPA treatment induces beneficial effects in GI systems. For example, LPA protected and rescued gastrointestinal damage induced by radiation and chemotherapy $[49,50]$. LPA also facilitates gastrointestinal wound healing $[51,52]$. Pharmacologically, we do not know how the present stimulating effects of gintonin on the pacemaker activity of ICC and GI motility are associated with beneficial LPA effects on the GI system. Gintonin-mediated stimulation of GI tract motility might contribute to the amelioration of disease-related GI activity dysfunctions, such as those in diabetic mellitus (Fig. 6). Also, LPA evokes multiple physiological responses via $G$ proteins in most cell types [47]. The LPA receptor was first cloned from the developing brain and was discovered to be a G protein coupled receptor (GPCR) [53]. Currently, at least six different subtypes of the LPA receptor are known to exist in tissues $[48,54]$. The

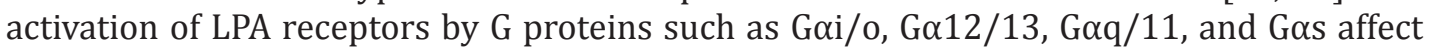
many pathophysiological conditions [48]. In ICC, gintonin may activate the $\mathrm{G} \alpha \mathrm{q} / 11$ protein and induce the activation of PLC and PKC, which then depolarizes the membrane resulting in depolarization of pacemaker activity. Future studies should investigate which G protein is involved in this process. In Fig. 8, the generation of transient ANO1-like currents by gintonin was observed. We believe this may be due to the desensitization of LPA receptors by prolonged stimulation which is a common phenomenon among GPCRs including muscarinic receptors. Desensitization is one of the most important characteristics of GPCRs. In ICC, beta-arrestin, ubiquitin and phosphorylation among other factors may be involved in the mechanism of desensitization of GPCRs [55-57]. In the future, we will perform experiments to explore the mechanisms of desensitization by gintonin.

Gintonin comprises about $0.2 \%$ of ginseng [33]. Gintonin has been shown to contain two proteins, a ginseng major latex-like protein 151 (GLP151) and a ginseng ribonucleaselike storage protein [32]. GLP 151 belongs to the Bet v1 superfamily. GLP151 contains hydrophobic ligand-binding sites and a glycine-rich region that binds to phosphate groups [32]. Currently, we are investigating the possibility that GLP151 binds to LPA and induces LPA to exhibit gintonin action. In previous studies, we demonstrated that gintonin regulates diverse $\mathrm{Ca}^{2+}$-dependent ion channels such as $\mathrm{BK}_{\mathrm{Ca}^{\prime}} \mathrm{Ca}^{2+}$-activated $\mathrm{Cl}^{-}$, and $\mathrm{Kv} 1.2$ channels, and receptors such as NMDA and P2X $\mathrm{X}_{1}$ receptors via endogenous LPA receptor activation [32-34, $58,59]$. In an in vivo study, gintonin showed anti-Alzheimer's disease effects by activating a non-amyloidogenic pathway via LPA receptors and reduced amyloid plaque formations in the cortex and hippocampus [60]. In the present study, we examined the effects of gintonin on the GI system and found that gintonin induced depolarization of the membrane potentials during pacemaker activity in ICC and activated $\mathrm{Ca}^{2+}$-dependent ANO1 channel 
Fig. 11. Hypothetical schematic signaling pathway of gintonin-induced membrane depolarization in ICC. Gintonin-induced membrane depolarization appeared to be mediated by LPA receptors via G proteins, and the PLC and PKC pathways, as well as the subsequent increase in intracellular $\mathrm{Ca}^{2+}$ levels from the sarcoplasmic reticulum (SR). Our observations also indicate that ANO1 currents are activated in ICC by gintonin.

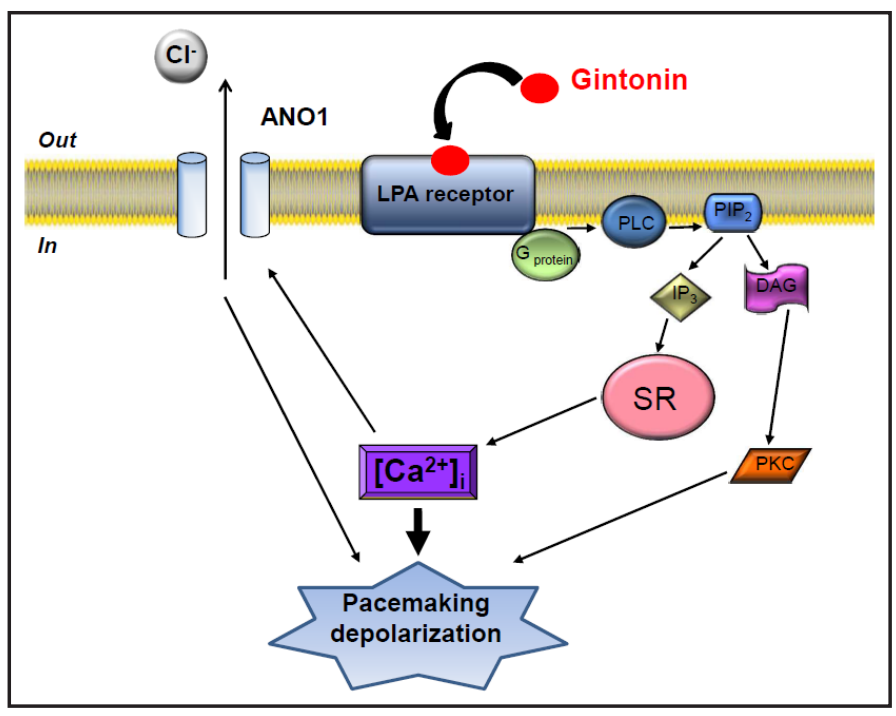

currents. Furthermore, gintonin stimulated in vivo GI contractility, indicating that gintonin could exert its effects on the GI system as well as the nervous system. We summarized the signaling pathways of gintonin-mediated regulation of pacemaker activity in mouse ICC and GI motility in Fig. 11.

ICC serve as the pacemaker cells of the GI tract [46]. ICC generate spontaneous pacemaker potentials and conduct the slow waves into the smooth muscle syncytium because ICC are electrically coupled to neighboring smooth muscle cells $[10,11,46]$. Smooth muscle cells respond to the slow wave depolarizations with the activation of L-type $\mathrm{Ca}^{2+}$ channels. The smooth muscle response is also regulated by neural inputs. Both excitatory and inhibitory enteric motor neurons are closely associated with ICC. Neural modification of the smooth muscle response, via ICC, modulates excitation-contraction coupling between slow waves and contractions [46]. Therefore, if a loss or dysfunction occurs in of any part of the ICC, smooth muscle cells and neurons will be affected, which can result in GI motility disorders [61].

In this study, gintonin depolarized the pacemaker potential and decreased the frequency and amplitude of pacemaker activity. Generally, if the pacemaker potential in ICC is depolarized, the frequency and amplitude of pacemaker activity will decrease and smooth muscles will contract. For example, carbachol (CCh) depolarizes pacemaker potentials and produces tonic inward currents with reduced frequency and amplitude in pacemaker currents in cultured intestinal ICC [62]. In cultured gastric ICC, acetylcholine (ACh) or CCh produced membrane depolarization observed in intact gastrointestinal smooth muscle and produced tonic inward pacemaker currents [63]. Additionally, substance P is also a major excitatory neurotransmitter in the gastrointestinal tract that depolarizes pacemaker potentials and reduces the frequency and amplitude of the pacemaker potentials in ICC [64]. Therefore, gintonin could affect the pacemaker activities of ICC and the consequent contractions of smooth muscle cells. However, there is a problem that the time difference in the culture period between single ICC (12hrs) versus ICC clusters (24hrs). We do not think that the mechanisms observed in ICC clusters at $24 \mathrm{hrs}$ could be fundamentally different from those studied before $12 \mathrm{hrs}$. ANO1 was well expressed in ICC within 12 hrs culture period, but after that, ANO1 expression was decreased with time. However, at 24 hrs, ANO1 expression was decreased but did not disappear. To experiment certainly the ANO1 effects in ICC, we experimented the single ICC within 12 hrs. But, within 12 hrs, it was very difficult to experiment the ICC cluster type and therefore, we experimented $24 \mathrm{hrs}$. We think that at $24 \mathrm{hrs}$, because ANO1 expression is decreased but does not disappear, there is no problem to experiment in ICC cluster type. Gintonin is a very specialized agent that depolarized the pacemaker activity (Fig. 1) and induced PKC-sensitive pacemaker potentials (Fig. 4). In 
conclusion, we think that gintonin may increase GI motility at the tissue level considering that 1) gintonin increased the ANO1 currents in single ICC and 2) depolarized the pacemaker activity in ICC cluster type.

Fig. 7 and 8 show that ANO1 currents were evoked by ionomycin or gintonin. However, from the traces, it appears that there was no current at $-60 \mathrm{mV}$ before gintonin or ionomycin was applied. Therefore, several people may wonder how it could be responsible for the spontaneous activity shown in this study that occurs in the absence of these agents. To generate spontaneous activity, the change of intracellular $\mathrm{Ca}^{2+}$ concentration $\left(\mathrm{Ca}^{2+}\right.$ oscillation) is critical. For handling intracellular $\mathrm{Ca}^{2+}$ concentration, $\mathrm{Ca}^{2+}$-ATPase \& $\mathrm{IP}_{3}$ receptor in ER and various $\mathrm{Ca}^{2+}$ ion channels including $\mathrm{L}-$, T-type $\mathrm{Ca}^{2+}$ channels play divergent roles that control the spontaneous rhythmicity. In this situation, AN01 periodically activated by the $\mathrm{Ca}^{2+}$ oscillation to generate $\mathrm{Cl}^{-}$current could induce membrane depolarization. When we measured spontaneous activity, we used ICC cluster. As the reviewer already knows, those ICC clusters consist of hundreds of ICC which connected each other by gap junction. Therefore even if we made the whole-cell patch with low calcium buffer solution to one among ICC cluster, remaining ICC cluster cells were intact and able to generate spontaneous activity which could transmit through the gap junction. To measure the ANO1 currents in single ICC, we used the low calcium buffer solution containing 0.1 mM EGTA. Because single ICC was buffered by low calcium buffer solution, ANO1 could not be activated. However, when we treated ionomycin or gintonin that can increase intracellular $\mathrm{Ca}^{2+}$ concentration as GPCR agonist (acetylcholine etc), eventually we could easily observe ANO1 activation under low calcium buffer solution. In summary, because ICC cluster was not affected by the low calcium buffer pipette solution, we could easily measure the spontaneous activity which mediated by AN01 current through the gap junction. In single ICC whole-cell patch clamp, we could not detect basal $\mathrm{Cl}^{-}$current due to the low calcium buffer pipette solution. Nevertheless, because we used weak $\mathrm{Ca}^{2+}$ chelating buffer ( $0.1 \mathrm{mM} \mathrm{EGTA}$ ), we could easily generate ANO1 current by ionomycin or gintonin that can increase intracellular $\mathrm{Ca}^{2+}$ concentration. The pacemaker potentials mainly consist of TRPM7 channels at upstoke and ANO1 channels at plateau phase. Under low EGTA condition, gintonin or ionomycin induces ANO1 activaton in single ICC and might contribute the pacemaker potentials in native GI tissues even though the AN01 effect is small in cultured ICC clusters. More studies are needed why the gintonininduced depolarization inhibit the pacemaker potential on contrary to other depolarization agents like acetylcholine. Considering no effect of gintonin on TRPM7 channels, other cation channels such as $\mathrm{Na}^{+}$-leak channels (NALCN) [64], T-type $\mathrm{Ca}^{2+}$ channels [65] or other TRP channels, might affect the initial upstoke phase of pacemaker potentials.

In a previous report using mouse ICC, GTS fractions depolarized cell membranes with increased tonic inward currents, which were activated by NSCCs via external $\mathrm{Ca}^{2+}$ influx, PLC activation, and by $\mathrm{Ca}^{2+}$ release from internal stores in a GTP-binding protein- and PKCindependent manner [66]. Thus, although the previous study also showed that GTS fractions regulate pacemaker activity in ICC, the present study partially overlaps with the previous report but explores different aspects of regulation. First, gintonin action was sensitive to GDP $\beta$ S and PKC inhibitors (Fig. 3 and 4). In addition, gintonin action was related to ANO1 $\mathrm{Cl}^{-}$ channels but not NSCCs (Fig. 6, 7 and 8). Thus, ginseng might contain two active components for pacemaker activity regulation in ICC. One may be related to gintonin and affect G proteincoupled LPA receptor and ANO1 $\mathrm{Cl}^{-}$channel activation. The other component may be related to ginsenosides and affect NSCCs through NSCC signaling mechanisms.

In the present study, we used T16Ainh-A01 as a selective ANO1 blocker. Although T16Ainh-A01 is a selective blocker of the anoctamin family of CACCs, it does not discriminate between anoctamin subtypes [67]. Hwang et al. [24] have shown that a number of different anoctamins are expressed by ICC. Therefore, it is certainly possible that ICC pacemaker potentials are dependent on other anoctamins as well as ANO1.

We think that ANO1 may be involved in the upstroke of the pacemaker potential. However, another ion channels (Ex. TRPM7 channels and so on) are also involved in the upstroke of the pacemaker potential. In ANO1 K/O mouse [30], the slow wave and the 
upstroke part of pacemaker potential were still remained. Therefore, many ion channels (TRPM7 and ANO1 and so on) are involved in the upstroke of the pacemaker potentials. In ICC, excitatory neurotransmitter induced the depolarization and reduced the amplitude and frequency. Gintonin also induced the depolarization and reduced the amplitude and frequency. However, the amplitude reduction of the pacemaker potentials by gintonin is larger than the other effects. Until now, we do not understand the exact ion channel mechanisms during upstroke and plateau phase in pacemaker potentials. Therefore, it may be very difficult to know the exact effects of gintonin in pacemaker potentials and we have to investigate which ion channels are involved in amplitude and frequency of pacemaker potentials in future. Also, we cannot explain the exact mechanism of the increase of motility rate and ITR. However, we thought that even if the amplitude and frequency of pacemaker potential was decreased, gintonin might increase intracellular $\mathrm{Ca}^{2+}$ concentrations and depolarize the resting membrane potentials of ICC. Thereafter, this stimulation might be conducted to smooth muscle or enteric nervous system. Therefore, this depolarization of pacemaker potentials might induce the increase motility rate and ITR. We think that this is a unique characteristics of gintonin and in future, we will investigate this and establish a connection between ICC and intestinal transit.

In conclusion, we found that gintonin modulates the membrane depolarization of pacemaker activity in a G protein-, PLC-, $\mathrm{Ca}^{2+}$ - and PKC-dependent manner via LPA receptor activation. Furthermore, ANO1 is involved in the gintonin-induced regulation of pacemaker activity in cultured murine ICC. Finally, the present study shows that gintonin could be a novel candidate for drug development that targets constipation or slow GI transit.

\section{Acknowledgements}

This work was supported by the Basic Science Research Program (2011-0021144 to S. Y. Nah, 2011-0014404 to J. H. Nam and 2010-0021347 to B. J. Kim) and the Priority Research Centers Program (2012-0006686 to S. Y. Nah) through the National Research Foundation of Korea (NRF), which is funded by the Ministry of Education, Science, and Technology and by the BK21 plus project fund to S. Y. Nah.

\section{Disclosure Statement}

The authors have no potential conflict of interest to declare.

\section{References}

1 Saito H, Tsuchiya M, Naka S, Takagi K: Effects of Panax Ginseng root on conditioned avoidance response in rats. Jpn J Pharmacol 1977;27:509-516.

$\checkmark 2$ Chen X: Cardiovascular protection by ginsenosides and their nitric oxide releasing action. Clin Exp Pharmacol Physiol 1996;23:728-732.

- Gillis CN: Panax ginseng pharmacology: a nitric oxide link?. Biochem Pharmacol 1997;54:1-8.

4 Nah SY, Kim DH, Rhim H: Ginsenosides: are any of them candidates for drugs acting on the central nervous system?. CNS Drug Rev 2007;13:381-404.

5 Furukawa Y, Shiga Y, Hanyu N, Hashimoto Y, Mukai H, Nishikawa K, Aoki T: Effect of Chinese herbal medicine on gastrointestinal motility and bowel obstruction. Jpn J Gastroenterol Surg 1995;28:956-960.

6 Hashimoto K, Satoh K, Kase Y, Ishige A, Kubo M, Sasaki H, Nishikawa S, Kurosawa S, Yakabi K, Nakamura T: Modulatory effect of aliphatic acid amides from Zanthoxylum piperitum on isolated gastrointestinal tract. Planta Med 2001;67:179-181. 


\begin{tabular}{|c|c|c|}
\hline Cellular Physiology & Cell Physiol Biochem 2014;34:873-890 & \\
\hline and Biochemistry & $\begin{array}{l}\text { DOI: } 10.1159 / 000366306 \\
\text { Publisned online: August 21, } 2014\end{array}$ & $\begin{array}{l}\text { O } 2014 \text { S. Karger AG, Basel } \\
\text { www.karger.com/cpb }\end{array}$ \\
\hline
\end{tabular}

7 Murata P, Hayakawa T, Satoh K, Kase Y, Ishige A, Sasaki H: Effects of Dai-kenchu-to, a herbal medicine, on uterine and intestinal motility. Phytother Res 2001;23:29-41.

8 Shibata C, Sasaki I, Naito H, Ueno T, Matsuno S: The herbal medicine Dai-Kenchu-Tou stimulates upper gut motility through cholinergic and 5-hydroxytryptamine 3 receptors in conscious dogs. Surgery 1999;126:918-924.

- Kawasaki N, Nakada K, Nakayoshi T, Furukawa Y, Suzuki Y, Hanyu N, Yanaga K: Effect of Dai-kenchu-to on gastrointestinal motility based on differences in the site and timing of administration. Dig Dis Sci 2007;52:2684-2694.

10 Ward SM, Burns AJ, Torihashi S, Sanders KM: Mutation of the proto-oncogene c-kit blocks development of interstitial cells and electrical rhythmicity in murine intestine. J Physiol 1994;480:91-102.

-11 Huizinga JD, Thuneberg L, Klüppel M, Malysz J, Mikkelsen HB, Bernstein A: W/kit gene required for interstitial cells of Cajal and for intestinal pacemaker activity. Nature 1995;373:347-349.

12 Hou X, Yin J, Liu J, Pasricha PJ, Chen JD: In vivo gastric and intestinal slow waves in W/WV mice. Dig Dis Sci 2005;50(7):1335-1341.

13 Kim BJ, Lim HH, Yang DK, Jun JY, Chang IY, Park CS, So I, Stanfield PR, Kim KW: Melastatin-Type Transient Receptor Potential Channel 7 Is Required for Intestinal Pacemaking Activity. Gastroenterology 2005;129:1504-1517.

14 Lee JH, Kim SY, Kwon YK, Kim BJ, So I: Characteristics of the cholecystokinin-induced depolarization of pacemaking activity in cultured interstitial cells of Cajal from murine small intestine. Cell Physiol Biochem. 2013;31:542-554.

15 Koh SD, Jun JY, Kim TW, Sanders KM: A Ca ${ }^{2+}$-inhibited non-selective cation conductance contributes to pacemaker currents in mouse interstitial cell of Cajal. J Physiol 2002;540:803-814.

16 Kim BJ, So I, Kim KW: The relationship of TRP channels to the pacemaker activity of interstitial cells of Cajal in the gastrointestinal tract. J Smooth Muscle Res 2006;42:1-7.

17 Huizinga JD, Zhu Y, Ye J, Molleman A: High conductance chloride channels generate pacemaker currents in interstitial cells of Cajal. Gastroenterology 2002;123:1627-1636.

18 Zhu MH, Kim TW, Ro S, Yan W, Ward SM, Koh SD, Sanders KM: A Ca+-activated Cl-conductance in interstitial cells of Cajal linked to slow wave currents and pacemaker activity. J Physiol 2009;587:4905-4918.

19 Zhu Y, Mucci A, Huizinga JD: Inwardly rectifying chloride channel activity in intestinal pacemaker cells. Am J Physiol Gastrointest Liver Physiol 2005;288:G809-821.

20 Park SJ, Mckay CM, Zhu Y, Huizinga JD: Volume-activated chloride currents in interstitial cells of Cajal. Am J Physiol Gastrointest Liver Physiol 2005;289:G791-797.

21 Huizinga JD, Zhu Y, Ye J, Molleman A: High-conductance chloride channels generate pacemaker currents in interstitial cells of Cajal. Gastroenterology 2002;123:1627-1636.

22 Parsons SP, Kunze WA, Huizinga JD: Maxi-channels recorded in situ from ICC and pericytes associated with the mouse myenteric plexus. Am J Physiol Cell Physiol. 2012;302:C1055-1069.

23 Yang YD, Cho H, Koo JY, Tak MH, Cho Y, Shim WS, Park SP, Lee J, Lee B, Kim BM, Raouf R, Shin YK, Oh U: TMEM16A confers receptor-activated calcium-dependent chloride conductance. Nature 2008;455:12101215.

-24 Hwang SJ, Blair PJ, Britton FC, O’Driscoll KE, Hennig G, Bayguinov YR, Rock JR, Harfe BD, Sanders KM, Ward SM: Expression of anoctamin 1/TMEM16A by interstitial cells of Cajal is fundamental for slow wave activity in gastrointestinal muscles. J Physiol 2009;587:4887-4904.

25 Namkung W, Yao Z, Finkbeiner WE, Verkman AS: Small-molecule activators of TMEM16A, a calciumactivated chloride channel, stimulate epithelial chloride secretion and intestinal contraction. FASEB J 2011;25:4048-4062.

-26 Sanders KM, Zhu MH, Britton F, Koh SD, Ward SM: Anoctamins and gastrointestinal smooth muscle excitability. Exp Physiol. 2012;97:200-206.

27 Zhu Y, Golden CM, Ye J, Wang XY, Akbarali HI, Huizinga JD: ERG K+ currents regulate pacemaker activity in ICC. Am J Physiol Gastrointest Liver Physiol 2003;285:G1249-1258.

28 Torihashi S, Fujimoto T, Trost C, Nakayama S: Calcium oscillation linked to pacemaking of interstitial cells of Cajal: requirement of calcium influx and localization of TRP4 in caveolae. J Biol Chem. 2002;277:1919119197.

29 Bayguinov 0, Ward SM, Kenyon JL, Sanders KM: Voltage-gated Ca ${ }^{2+}$ currents are necessary for slow-wave propagation in the canine gastric antrum. Am J Physiol Cell Physiol 2007;293:C1645-1659. 


\begin{tabular}{|c|c|c|}
\hline Cellular & Cell Physiol Biochem 2014;34:873-890 & \\
\hline and Biochemistry & $\begin{array}{l}\text { DOI: } 10.1159 / 000366306 \\
\text { Publishea online: August 21, } 2014\end{array}$ & $\begin{array}{l}\text { O 2014 S. Karger AG, Basel } \\
\text { www.karger.com/cpb }\end{array}$ \\
\hline
\end{tabular}

30 Huang F, Rock JR, Harfe BD, Cheng T, Huang X, Jan YN, Jan LY: Studies on expression and function of the TMEM16A calcium-activated chloride channel. Proc Natl Acad Sci U S A 2009;106:21413-21418.

-31 Shahi PK, Choi S, Zuo DC, Kim MY, Park CG, Kim YD, Lee J, Park KJ, So I, Jun JY: The possible roles of hyperpolarization-activated cyclic nucleotide channels in regulating pacemaker activity in colonic interstitial cells of Cajal. J Gastroenterol 2014;49:1001-1010.

-32 Hwang SH, Shin TJ, Choi SH, Cho HJ, Lee BH, Pyo MK, Lee JH, Kang J, Kim HJ, Park CW, Shin HC, Nah SY: Gintonin, newly identified compounds from ginseng, is novel lysophosphatidic acids-protein complexes and activates G proteincoupled lysophosphatidic acid receptors with high affinity. Mol Cells 2012;33:151162.

33 Pyo MK, Choi SH, Hwang SH, Shin TH, Lee BH: Novel glycolipoproteins from ginseng. J Ginseng Res 2011;35:92-103.

-34 Choi SH, Lee BH, Hwang SH, Kim HJ, Lee SM, Kim HC, Rhim HW, Nah SY: Molecular mechanisms of largeconductance $\mathrm{Ca}^{2+}$-activated potassium channel activation by ginseng gintonin. Evid Based Complement Alternat Med 2013;2013:323709.

35 Lee JH, Choi SH, Lee BH, Hwang SH, Kim HJ, Rhee J, Chung C, Nah SY: Activation of lysophosphatidic acid receptor by gintonin inhibits Kv1.2 channel activity: involvement of tyrosine kinase and receptor protein tyrosine phosphatase $\alpha$. Neurosci Lett 2013;548:143-148.

-36 Mori M, Tsushima H: Activation of Rho signaling contributes to lysophosphatidic acid-induced contraction of intact ileal smooth muscle of guinea-pig. Can J Physiol Pharmacol 2000;78:729-736.

-37 Kraichely RE, Strege PR, Sarr MG, Kendrick ML, Farrugia G: Lysophosphatidyl choline modulates mechanosensitive L-type $\mathrm{Ca}^{2+}$ current in circular smooth muscle cells from human jejunum. Am J Physiol Gastrointest Liver Physiol 2009;296:G833-9.

-38 Ohta H, Sato K, Murata N, Damirin A, Malchinkhuu E, Kon J, Kimura T, Tobo M, Yamazaki Y, Watanabe T, Yagi M, Sato M, Suzuki R, Murooka H, Sakai T, Nishitoba T, Im DS, Nochi H, Tamoto K, Tomura H, Okajima F: Ki16425, a subtype-selective antagonist for EDG-family lysophosphatidic acid receptors. Mol Pharmacol 2003;64:994-1005.

-39 Yamada T, Sato K, Komachi M, Malchinkhuu E, Tobo M, Kimura T, Kuwabara A, Yanagita Y, Ikeya T, Tanahashi Y, Ogawa T, Ohwada S, Morishita Y, Ohta H, Im DS, Tamoto K, Tomura H, Okajima F : Lysophosphatidic acid (LPA) in malignant ascites stimulates motility of human pancreatic cancer cells through LPA1. J Biol Chem 2004;279:6595-6605.

40 Komori S, Kawai M, Takewaki T, Ohashi H: GTP-binding protein involvement in membrane currents evoked by carbachol and histamine in guinea-pig ileal muscle. J Physiol 1992;450:105-126.

41 Ogata R, Inoue Y, Nakano H, Ito Y, Kitamura K: Oestradiol-induced relaxation of rabbit basilar artery by inhibition of voltage-dependent Ca channels through GTP-binding protein. Br J Pharmacol 1996;117:351359.

42 Sakamoto T, Unno T, Matsuyama H, Uchiyama M, Hattori M, Nishimura M, Komori S: Characterization of muscarinic receptor-mediated cationic currents in longitudinal smooth muscle cells of mouse small intestine. J Pharmacol Sci 2006;100:215-226.

43 Aiello EA, Clement-Chomienne O, Sontag DP, Walsh MP, Cole WC: Protein kinase C inhibits delayed rectifier K+ current in rabbit vascular smooth muscle cells. Am J Physiol 1996;271:H109-119.

-44 Ward SM, Ordog T, Koh SD, Baker SA, Jun JY, Amberg G, Monaghan K, Sanders KM: Pacemaking in interstitial cells of Cajal depends upon calcium handling by endoplasmic reticulum and mitochondria. J Physiol 2000;525:355-361.

45 Choi S, Choi JJ, Jun JY, Koh JW, Kim SH, Kim DH, Pyo MY, Choi S, Son JP, Lee I, Son M, Jin M: Induction of pacemaker currents by DA-9701, a prokinetic agent, in interstitial cells of Cajal from murine small intestine. Mol Cells 2009;27:307-312.

46 Sanders KM, Koh SD, Ro S, Ward SM: Regulation of gastrointestinal motility--insights from smooth muscle biology. Nat Rev Gastroenterol Hepatol 2012;9:633-645.

47 Moolenaar WH: LPA: a novel lipid mediator with diverse biological actions. Trends Cell Biol 1994;4:213219.

48 Chun J, Hla T, Lynch KR, Spiegel S, Moolenaar WH: International union of basic and clinical pharmacology. LXXVIII. Lysophospholipid receptor nomenclature. Pharmacol Rev 2010;62:579-587. 


\begin{tabular}{|c|c|c|}
\hline Cellul & Cell Physiol Biochem 2014;34:873-890 & \\
\hline and Biochemistry & $\begin{array}{l}\text { Dol: 10.1159/000366306 } \\
\text { Publisnea onine: August 21, } 2014\end{array}$ & $\begin{array}{l}\text { O } 2014 \text { S. Karger AG, Basel } \\
\text { www.karger.com/cpb }\end{array}$ \\
\hline
\end{tabular}

49 Deng W, Balazs L, Wang DA, Van Middlesworth L, Tigyi G, Johnson LR: Lysophosphatidic acid protects and rescues intestinal epithelial cells from radiation- and chemotherapy-induced apoptosis. Gastroenterology 2002;123:206-216

50 Deng W, Shuyu E, Tsukahara R, Valentine WJ, Durgam G, Gududuru V, Balazs L, Manickam V, Arsura M, VanMiddlesworth L, Johnson LR, Parrill AL, Miller DD, Tigyi G: The lysophosphatidic acid type 2 receptor is required for protection against radiation-induced intestinal injury. Gastroenterology 2007;132:1834-1851

-51 Sturm A, Sudermann T, Schulte KM, Goebell H, Dignass AU: Modulation of intestinal epithelial wound healing in vitro and in vivo by lysophosphatidic acid. Gastroenterology 1999;117:368-377

-52 Hines OJ, Ryder N, Chu J, McFadden D: Lysophosphatidic acid stimulates intestinal restitution via cytoskeletal activation and remodeling. J Surg Res 2000;92:23-28

53 Hecht JH, Weiner JA, Post SR, Chun J: Ventricular zone gene-1 (vzg-1) encodes a lysophosphatidic acid receptor expressed in neurogenic regions of the developing cerebral cortex. J Cell Biol 1996;135:10711083.

54 Noguchi K, Herr D, Mutoh T, Chun J: Lysophosphatidic acid (LPA) and its receptors. Curr Opin Pharmacol 2009;9:15-23.

55 Liggett SB : Phosphorylation barcoding as a mechanism of directing GPCR signaling. Sci Signal 2011;4:pe36.

56 Marchese A, Trejo J: Ubiquitin-dependent regulation of G protein-coupled receptor trafficking and signaling. Cell Signal 2013;25:707-716.

57 Kaparianos A, Argyropoulou E, Spiropoulos K: The role of Beta-arrestins in respiratory pathophysiology and tumorigenesis: going a step beyond the cell surface. Eur Rev Med Pharmacol Sci 2012;16:1781-1794.

-58 Shin TJ, Kim HJ, Kwon BJ, Choi SH, Kim HB, Hwang SH, Lee BH, Lee SM, Zukin RS, Park JH, Kim HC, Rhim H, Lee JH, Nah SY: Gintonin, a ginseng-derived novel ingredient, evokes long-term potentiation through N-methyl-D-aspartic acid receptor activation: involvement of LPA receptors. Mol Cells 2012;34:563-572.

59 Choi SH, Kim HJ, Kim BR, Shin TJ, Hwang SH, Lee BH, Lee SM, Rhim H, Nah SY: Gintonin, a ginseng-derived lysophosphatidic acid receptor ligand, potentiates ATP-gated P2X1 receptor channel currents. Mol Cells 2013;35:142-150.

60 Hwang SH, Shin EJ, Shin TJ, Lee BH, Choi SH, Kang J, Kim HJ, Kwon SH, Jang CG, Lee JH, Kim HC, Nah SY: Gintonin, a ginseng-derived lysophosphatidic acid receptor ligand, attenuates Alzheimer's disease-related neuropathies: involvement of non-amyloidogenic processing. J Alzheimers Dis 2012;31:207-223.

61 Sanders KM, Ördög T, Koh SD, Ward SM: A Novel Pacemaker Mechanism Drives Gastrointestinal Rhythmicity. News Physiol Sci 2000;15:291-298.

62 So KY, Kim SH, Sohn HM, Choi SJ, Parajuli SP, Choi S, Yeum CH, Yoon PJ, Jun JY: Carbachol regulates pacemaker activities in cultured interstitial cells of Cajal from the mouse small intestine. Mol Cells 2009;27:525-531.

-63 Kim TW, Koh SD, Ordög T, Ward SM, Sanders KM: Muscarinic regulation of pacemaker frequency in murine gastric interstitial cells of Cajal. J Physiol 2003;546:415-425.

64 Kim BJ, Chang IY, Choi S, Jun JY, Jeon JH, Xu WX, Kwon YK, Ren D, So I : Involvement of Na+-leak channel in substance P-induced depolarization of pacemaking activity in interstitial cells of Cajal. Cell Physiol Biochem 2012;29:501-510.

65 Zheng H, Park KS, Koh SD, Sanders KM: Expression and function of a T-type $\mathrm{Ca}^{2+}$ conductance in interstitial cells of Cajal of the murine small intestine. Am J Physiol Cell Physiol 2014;306:C705-713.

66 Kim HS, Parajuli SP, Yeum CH, Park JS, Jeong HS, So I, Kim KW, Jun JY, Choi S: Effects of ginseng total saponins on pacemaker currents of interstitial cells of Cajal from the small intestine of mice. Biol Pharm Bull 2007;30:2037-2042.

67 Martins JR, Faria D, Kongsuphol P, Reisch B, Schreiber R, Kunzelmann K: Anoctamin 6 is an essential component of the outwardly rectifying chloride channel. Proc Natl Acad Sci USA 2011;108:18168-18172. 